\title{
COMPARISON OF TWO METHODS FOR MONITORING URBAN FORESTS HEALTH
}

\author{
USPOREDBA DVIJU METODA ZA PRAĆENJE \\ ZDRAVSTVENOG STANJA URBANIH ŠUMA
}

\author{
Nikica OGRIS ${ }^{1}$, Tine HAUPTMAN² ${ }^{2}$ Maarten de GROOT ${ }^{3}$, Dušan JURC ${ }^{4}$
}

\begin{abstract}
SUMIMARY
We compared the performance of two methods for monitoring urban forest health. The first was based on a systematic grid (ISM), and the second on non-linear transects (UFMO). Both methods were tested during July and August 2013 in the Rožnik urban forest in the Municipality of Ljubljana (MOL). We assessed crown condition and damaging agents on 15 ISM plots, surveying an area of 92 a $\left(\right.$ are $\left.=100 \mathrm{~m}^{2}\right)$ in 1,640 minutes. By comparison, the UFMO method was used to survey an area of 518 a in 1,700 minutes. The performance of the ISM and the UFMO methods was $17.8 \mathrm{~min} / \mathrm{a}$ and $3.28 \mathrm{~min} / \mathrm{a}$, respectively. According to the time/area performance measure, the UFMO method performed 5.4 times better than the ISM method. The UFMO method recorded 1.5 times more damaging agents per hour, 2.7 times more trees per hour, and 13.4 times more dead standing trees per hour. It also suggested 7.0 times more management measures per hour. However, the density of the data gathered was 7.1 times higher for the ISM method. According to the chosen comparison measures, the overall performance of the UFMO method exceeded the ISM method in all chosen performance measures expressed in relative time except the amount of data gathered. We conclude that, for the same sampling cost, the ISM approach produces an unbiased, but imprecise, estimate of overall forest health, while the UFMO method produces a biased, but more precise, estimate. We discuss possible improvements and further limitations of the UFMO method with an emphasis on the differences between the two methods of monitoring and surveying forest health. We conclude, that the ISM monitoring method can be supplemented with the UFMO surveying method to capitalize on the potential synergies of combining both approaches.
\end{abstract}

KEY WORDS: bias, ICP Forests, performance evaluation, survey, systematic grid, transect

\section{INTRODUCTION}

\section{UVOD}

The benefits of urban forests are vast. They are an integral part of the green infrastructure of cities, providing urban society with an essential range of goods and services, including environmental, ecological, economic, and social functions, all of which contribute to sustainable development (Nilsson et al., 2012). To manage an urban forest, it is vital to understand the resource. Monitoring is an inte- gral component of programs that sustain healthy community forests and is an early and essential activity for planning and implementing management activities (McPherson, 1993). Comprehensive monitoring programs have been developed for forest health and other natural resources. However, little of this engagement has been directed towards monitoring urban tree health, despite the fact that increasing environmental awareness is influencing attitudes towards urban trees, forests, and global health.

\footnotetext{
Dr. Nikica Ogris, Tel.: + 3861 2007833, Fax: + 3861 2573589, E-mail: nikica.ogris@gozdis.si

${ }^{2}$ Dr. Tine Hauptman, E-mail: tine.hauptman@bf.uni-li.si

${ }^{3}$ Dr. Maarten de Groot, E-mail: maarten.degroot@gozdis.si

${ }^{4}$ Prof. dr. Dušan Jurc, Slovenian Forestry Institute, Večna pot 2, 1000 Ljubljana, Slovenia, E-mail: dusan.jurc@gozdis.si
} 
The only unified and integrated forest monitoring system that is currently in use is the International Co-operative Programme on the Assessment and Monitoring of Air Pollution Effects on Forests (ICP Forests), which was established in 1985 by the Convention on Long-range Transboundary Air Pollution under the United Nations Economic Commission for Europe (Lorenz, 2010). ICP Forests was developed in response to the widespread concern that air pollution could affect forest condition. At present, 41 European countries, as well as the United States of America and Canada, are participating in the Programme, which includes assessments according to harmonized methods following the ICP Forests Manual and which has developed into an important platform for the exchange of expert knowledge.

ICP Forest health monitoring is implemented at two levels: Level I, large-scale monitoring, and Level II, intensive site monitoring (ISM). Approximately 7,000 Level I plots have been established across Europe on a $16 \times 16 \mathrm{~km}$ grid. The data taken in Level I plots include annual crown defoliation visible on a total of 10-24 trees. The sample plots and trees are selected using a statistically sound procedure (Ferretti et al., 2010). Many authors have questioned and criticized the use of crown condition as a main indicator of forest health (e.g., Innes, 1993; Ferretti, 1997; Ferretti and Chiarucci, 2003; Seidling, 2004). Crown defoliation may be a good indicator of tree stress, but measuring it accurately requires extensive training of field personnel. Nevertheless, estimates can still vary considerably. Furthermore, the spatial coverage and spatial specificity of the systematic grid are inadequate when we want to focus on urban forest health problems along walking paths and roads, and on sparse but important damaging factors. Monitoring is an essential activity for management planning; however, we do not know if inventories are being utilized to their full potential in terms of producing management plans (Keller and Konijnendijk, 2012).

We argue that the ICP Forests method shows poor performance in assessing urban forest health: The economic performance is poor, and the number of direct management measures that can be acquired from the monitoring results is low. Therefore, one of the goals of this study was to develop an economically feasible method for surveying urban forest health that will result in more direct management measures.

Many of the functions of urban forests are recreational activities, such as walking, jogging, and biking, which depend on green infrastructure, such as roads, walking paths, parks, and playgrounds (Arnberger, 2006). The paths are surrounded by trees, which may represent an immediate security risk to a visitor in the form of damaged trees and falling branches. Surveying urban forest health should also include walking paths and roads. However, ICP Forests is based on a systematic grid that covers only a small portion of these highly important areas in urban forests. Therefore, another approach is needed to survey these areas, e.g. non-linear transects that correspond to the nature of walking paths, roads and forest edges, which are all essentially line elements.

Forest tree diseases and other damaging agents are numerous, and their distribution is often limited to a small area, even to a single tree. It is difficult to glean information on sparsely distributed damaging factors with a systematic grid. To cover more area, transects could be an alternative. However, cutting straight line transects through dense forest is time consuming and expensive when large areas need to be surveyed for rare or highly clustered damaging agents. Existing forest paths and roads may be suitable as line transects even though they do not, in general, run straight. Furthermore, roads and trails are not established randomly within an area but are generally found in areas with suitable terrain. There may well be a correlation between terrain and site factors that can influence tree response to insects and pathogens. More importantly, roads and trails receive much higher levels of public use than elsewhere within an urban forest, and consequently trees in the vicinity of roads and trails are more likely to be damaged or stressed as a result. Therefore, the use of existing paths involves bias resulting from the unrepresentative sampling of available green areas, and this must be weighed against the increase in coverage (Hiby and Krishna, 2001).

We developed a non-linear transect method in the frame of the EMoNFUr Project, Establishing a Monitoring Network to Assess Lowland Forest and Urban Plantations in Lombardy and Urban Forests in Slovenia (LIFE10 ENV/ IT/000399), for comparison purposes and as a competitive alternative for assessing urban forest health. We named it the Urban Forest Management Oriented (UFMO) method (Ogris et al., 2013), and it is described in detail in the methods section below.

Our aim was to compare the efficiency of the ISM and UFMO methods for monitoring tree health in urban forests. We predicted that the UFMO method would record more damage that might compromise the urban forest visitor's security because we surveyed trees within the vicinity of forest paths. The nature of line transects dictates that the surveyed trees are closer to each other, which means assessments can be conducted more efficiently, and a larger area can be covered.

\section{METHODS METODE}

The data were collected according to two methods. The first method was performed following the rules of Intensive Site Monitoring (ISM) developed by ICP Forests Expert Panel on Crown Condition and Damage Causes (Eichhorn et al., 


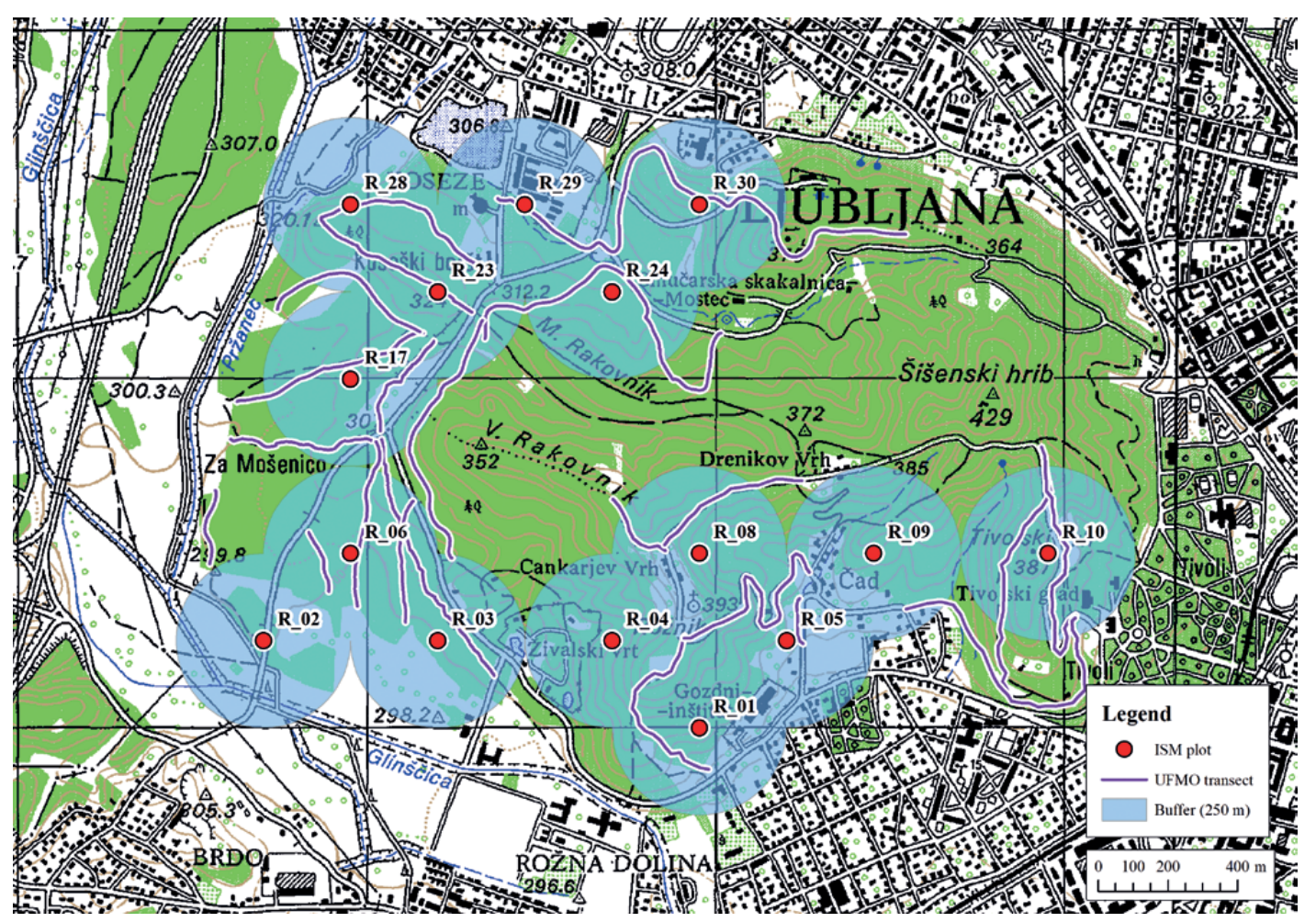

Figure 1. ISM plots and UFMO tracks assessed for damaging agents in the urban forest of the Tivoli, Rožnik and Šiška Hill Landscape Park in Ljubljana in 2013

Slika 1. ISM plohe i staze UFMO na kojima je izvršena procjena štetnih čimbenika u urbanoj šumi Parka prirode Tivoli, Rožnik i Šiška u Ljubljani 2013. godine

2016). The second method was the UFMO method (Ogris et al., 2013). Assessments and measurements by both methods were carried out during July and August 2013 in the same area of the Tivoli, Rožnik and Šiška Hill Landscape Park in the Municipality of Ljubljana (MOL), Slovenia (Fig. 1, Latitude $46.0514 \mathrm{~N}$ and Longitude $14.4779 \mathrm{E})$, by the same three forest health experts.

\section{ISM method - ISM metoda}

Thirty-two permanent forest-monitoring plots on a $250 \times$ $250 \mathrm{~m}$ systematic grid were established in July 2013 in the Tivoli, Rožnik and Šiška Hill Landscape Park in Ljubljana (Padoa - Schioppa et al., 2012). From these 32 plots, only 15 plots were chosen for ISM (Fig. 1). The centroid of each plot was marked with an iron pole so that the measurements could be repeated in following years.

The measurements and assessments were performed on the 15 sampling plots in July 2013 according to the ISM monitoring protocol (Padoa - Schioppa et al., 2012; Eichhorn et al., 2016). Data on trees of different dimensions (based on a range of diameter at breast heights, DBH) were collected using concentric circles. Within the plots, trees, dead wood, and small trees were inventoried: $30 \mathrm{~m}^{2}$ plot - small trees $(\mathrm{DBH}<10 \mathrm{~cm}) ; 200 \mathrm{~m}^{2}$ plot - standing trees and dead wood $(\mathrm{DBH} \geq 10 \mathrm{~cm} \mathrm{\&}<30 \mathrm{~cm}) ; 600 \mathrm{~m}^{2}$ plot - standing trees $(\mathrm{DBH} \geq 30 \mathrm{~cm}) ; 2,000 \mathrm{~m}^{2}$ plot - dead $\operatorname{wood}(\mathrm{DBH} \geq 30 \mathrm{~cm})$, site and stand characteristics. On the plot level the following attributes were recorded (14): GPS location, type of relief, exposition, stoniness, rockiness, slope, type of forest, developmental stage of the stand, canopy closure, regeneration, naturalness, homogeneity of the stand, forest management, forest characteristics, and age of dominant trees. The following attributes of standing live trees were gathered (5): tree species, tree location (distance and azimuth), status of the tree, diameter at breast height, and social class. Dead wood on the plot was described with following attributes (6): type of dead biomass, tree species, DBH, length, height, and decay class. Additional attributes were gathered for small trees with a DBH of less than $10 \mathrm{~cm}$ (6): tree species, $\mathrm{DBH}$, height, origin class, damage class, and other tree species present. Tree condition on the plot was described with the following variables (11): percentage of defoliation, affected part of the tree, specification of the affected part, location in the crown, symptom, symptom specification, causal agents, age of damage, damage extent on the trunk (\% and area class in $\mathrm{dm}^{2}$ ), and management measure suggested. Each tree could have several damaging agents. Furthermore, the time needed for the plot inventory was recorded.

\section{UFMO method - UFMO metoda}

Each UFMO plot was represented by a footpath, i.e. a nonlinear transect. The transect was recorded by a GPS track. 
During our movement along the path, we inventoried only damaged trees with a $\mathrm{DBH}$ exceeding $10 \mathrm{~cm}$ that were inside a 2- $m$ wide area on either side of the path and required management measures (salvage cutting, pruning, sanitation cutting, thinning, etc.). Visibly healthy trees were not considered. When a damaged tree was found, we recorded the GPS location of the tree and the number of the point in a consecutive manner, which represented an identification number to which all other data regarding the damaged tree were referenced. For the damaged tree, we measured its DBH and recorded the tree species and damaging factor / causal agent. We recorded all damaging factors for each single tree. Additionally, a management measure was suggested and recorded.

All attribute data were recorded on paper, digitized (copied into a Microsoft Excel table) and linked together with GPS data (tree location). In this way, the data became georeferenced.

The UFMO method was designed to focus on areas with management priority in the urban forest. Therefore, urban forest health surveys with the UFMO method usually include paths with a relatively high number of visitors and forest areas that are close to real estate, buildings, roads, etc. This was generally true also for our study in MOL. Additionally, we chose paths that were closer to the inventoried ISM plots, which made the ISM and UFMO methods spatially comparable. Furthermore, we wanted to make both methods comparable in terms of time; therefore, we took care to carry out both methods in approximately the same time.

\section{Monitoring vs. Surveying - Monitoring : pregledi}

In this paper monitoring refers to assessing a portion of a population to determine the condition of the resource, especially the change in the condition over time, and surveying refers to a procedure conducted over a defined period to determine the characteristics of a population in a defined area at the time of the survey. Monitoring is performed repeatedly on the same sampling plots, whereas surveying is usually performed on the same sampling plot only once. The ISM method is a monitoring method, and the UFMO method is a surveying method. The UFMO method uses non-linear transects as sampling plots. Non-linear transects can be used in a monitoring method when they are chosen randomly, and the assessment procedure is repeated in a defined time. Unlike the ISM method, the UFMO method does not use a representative sample and should not be used to make inferences regarding the entire population. In our study, the ISM method was used as the survey method even though it is basically the monitoring method.

\section{Data analysis - Analiza podataka}

The data analysis was focused on comparing the ISM and UFMO methods, i.e. a comparison of the performance be- tween ISM and the UFMO method. As the methods are not directly comparable, special care was dedicated to finding appropriate and comparable measures. The performance was measured by the time used to assess a certain area (time/area), the amount of data recorded, the number of damaging agents determined, the number of trees assessed, the number of standing dead trees recorded, and the number of management measures suggested. Simple linear regression along with the coefficient of determination $\left(\mathrm{R}^{2}\right)$ were used for explaining the possible correlation between the track length and the duration of the survey, between the track length and the number of management measures, and between the duration of the survey and the number of management measures. The significance of the correlation ( $p$ value) was calculated at the $95 \%$ confidence level.

The data gathered during this study are freely available at PANGAEA $^{\bullet}$ (Ogris et al., 2015).

\section{RESULTS}

\section{REZULTATI}

We assessed the crown condition and the damaging agents on 15 ISM plots. The performance time for the ISM and UFMO methods was $17.8 \mathrm{~min} / \mathrm{a}$ and $3.28 \mathrm{~min} / \mathrm{a}$, respectively. According to the time/area performance measure, the UFMO method performed 5.4 times better than the ISM method (Table 1). The ISM method recorded 30\% more data than the UFMO method in approximately the same time. The density of gathered data was 7.1 times higher for the ISM method. The UFMO method recorded

Table 1. Comparison of ISM and the UFMO method Tablica 1. Usporedba između ISM i UFMO metode

$\begin{array}{lcc}\text { Performance measure } & \text { ISM } & \text { UFMO } \\ \text { time (minutes) } & 1,640 & 1,700 \\ \text { area (are) } & 92.0 & 518.1 \\ \text { time/area (minutes/are) } & 17.8^{*} & 3.28^{*} \\ \text { data (n) } & 5,893 & 4,689 \\ \text { data (n/hour) } & 216 & 165 \\ \text { data (n/are) } & 64 & 9 \\ \text { damaging agents (n) } & 419 & 948 \\ \text { damaging agents (n/hour) } & 15.3 & 33.5 \\ \text { damaging agents (n/are) } & 4.6 & 1.8 \\ \text { trees (n) } & 260 & 730 \\ \text { trees (n/hour) } & 9.5 & 25.8 \\ \text { trees (n/are) } & 2.8 & 1.4 \\ \text { standing dead trees }(\mathrm{n}) & 13 & 181 \\ \text { standing dead trees }(\mathrm{n} / \mathrm{hour}) & 0.5 & 6.4 \\ \text { standing dead trees }(\mathrm{n} / \mathrm{ha}) & 14.1 & 34.9 \\ \text { management measures }(\mathrm{n})^{* *} & 101 & 730 \\ \text { management measures }(\mathrm{n} / \mathrm{hour}) & 3.7 & 25.8 \\ \text { management measures }(\mathrm{n} / \text { are) } & 1.1 & 1.4\end{array}$

*less is economically better; ${ }^{* *}$ categories of management measures were sanitation cutting, pruning, thinning, salvage cutting, and other tending 
Table 2. Most frequent damaging agents recorded by the ISM and UFMO methods (number of trees ha-1) Tablica 2. Najčešći štetni čimbenici zabilježeni metodama ISM i UFMO (broj stabala ha-1)

\begin{tabular}{llll} 
ISM & \multicolumn{3}{l}{ UFMO } \\
Lophodermium piceae (Fuckel) Höhn. & 50.0 & dead branches & 36.1 \\
Diplodia pinea (Desm.) J. Kickx f. & 45.7 & dead tree & 31.5 \\
Dryocosmus kuriphilus Yasumatsu, 1951 & 35.9 & Cryphonectria parasitica (Murrill) M.E. Barr & 23.7 \\
Lophodermium Chevall. & 31.5 & silvicultural measure & 11.2 \\
Cryphonectria parasitica (Murrill) M.E. Barr & 25.0 & mechanical damage & 10.8 \\
Rhynchaenus quercus Linnaeus, 1758 & 18.5 & weakening & 4.8 \\
light deficiency & 16.3 & Chalara fraxinea T. Kowalski & 4.8 \\
Erysiphe alphitoides (Griffon \& Maubl.) U. Braun \& S. Takam. & 16.3 & snowpacking & 3.5 \\
Defoliators & 12.0 & Erysiphe alphitoides (Griffon \& Maubl.) U. Braun \& S. Takam. & 3.3 \\
Apiognomonia Höhn. & 12.0 & leaning & 3.1 \\
Drought & 9.8 & cold crack & 2.9 \\
Tomicus minor Hartig, 1834 & 9.8 & Rhytisma acerinum (Pers.) Fr. & 2.7 \\
Tomicus piniperda Linnaeus, 1758 & 8.7 & windthrow & 2.7 \\
Rhynchaenus fagi Linnaeus, 1758 & 8.7 & Lophodermium Chevall. & 2.5 \\
Tischeria ekebladella Bjerkander, 1795 & 5.4 & Diplodia pinea (Desm.) J. Kickx f. & 2.5
\end{tabular}

2.2 times more damaging agents per hour, 2.7 times more trees per hour, and 13.4 times more standing dead trees per hour. It also suggested 7.0 times more management measures per hour. Therefore, the overall performance of the UFMO method exceeded the ISM method in all the chosen performance measures expressed in relative time except the amount of data gathered. Additionally, ISM performed better for two measures expressed in relative area, i.e. ISM recorded 2.5 times more damaging agents per are and 2.0 times more trees per are. Nevertheless, the UFMO method yielded 1.3 times more management measures per are, recorded 2.5 times more standing dead trees per hectare, and surveyed an area of one are 5.4 times faster than the ISM method.

Comparing the most frequent damaging agents between ISM and the UFMO method revealed two quite distinct lists of agents (Table 2). The ISM method recorded mostly defoliating agents affecting the crown, such as Lophodermium spp., Dryocosmus kuriphilus Yasumatsu (1951), and Diplodia pinea (Desm.) J. Kickx, whereas the UFMO met-

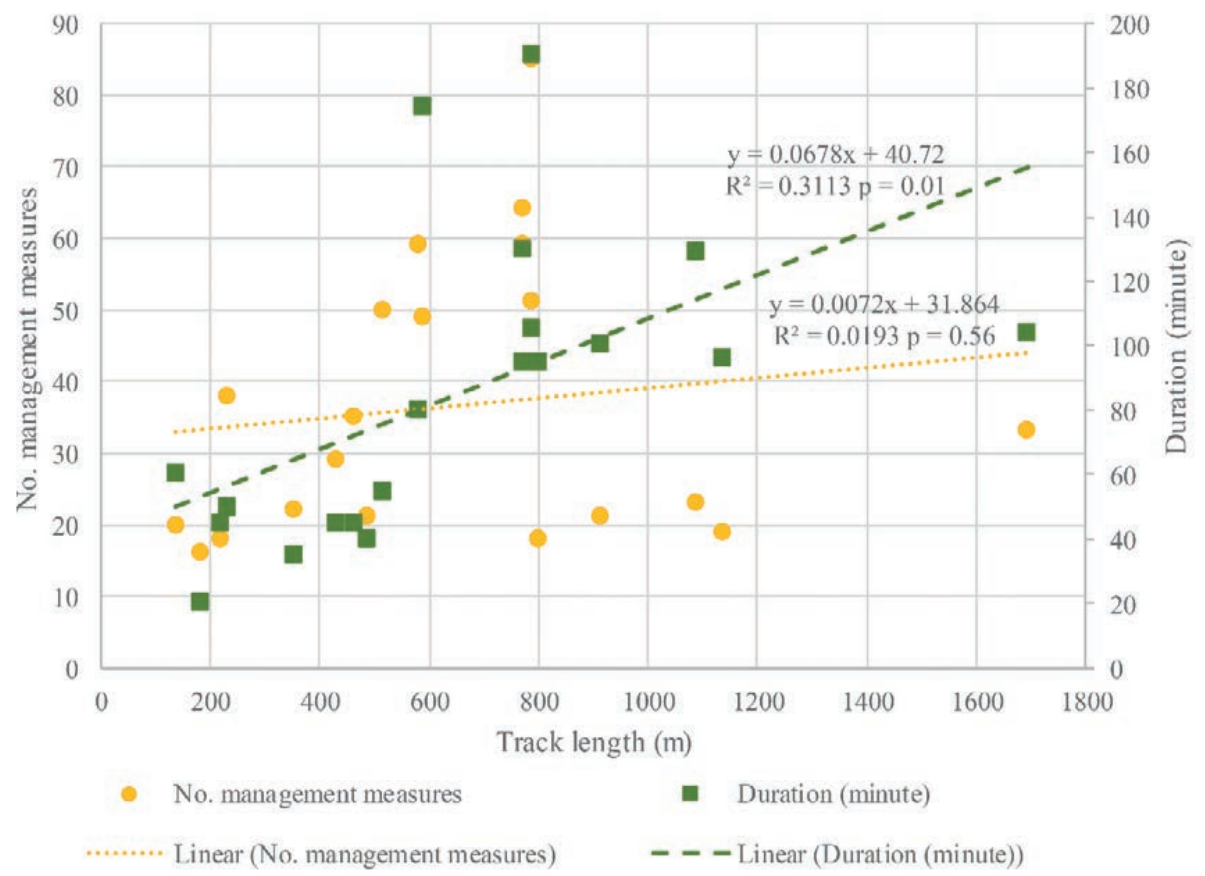

Figure 2. Influence of track length on the number of management measures and duration of survey using the UFMO method Slika 2. Utjecaj duljine staze na broj mjera upravljanja i trajanje istraživanja metodom UFMO 
hod recorded mostly damaging agents requiring management measures, e.g. dead branches (pruning), dead trees (salvage cutting), and Cryphonectria parasitica (Murrill) M.E. Barr (sanitation cutting).

The track length had only a slight positive influence on the duration of the survey $(p=0.01)$ and the number of management measures proposed $(p=0.56)$ by the UFMO survey (Fig. 2). However, the proportion of variance explained with the linear model was $31 \%$. A track of 1,000 $\mathrm{m}$ in length was surveyed in 108.5 minutes on average, and $39.1 \mathrm{ma}-$ nagement measures were suggested on average in that area. The length of the track was $138-1,695 \mathrm{~m}$ (648 m on average), the number of management measures suggested was 16-85 per track ( 36.5 on average), and the survey lasted 20-190 minutes ( 85 minutes on average) per track.

ISM suggested 0-24 (6.7 on average) management measures per plot. The survey of an ISM plot lasted 60-240 minutes (109 minutes on average). Comparing ISM and the UFMO method, the average number of management measures recorded per hour was 3.7 and 25.8, respectively (Fig. 3). However, the proportion of variance explained with the linear model was lower than $36 \%$.

Thirteen and 22 tree species were recorded in the ISM and UFMO methods, respectively (Table 3). Only 12 tree species were the same for both methods. With the ISM method, Pinus sylvestris L., Picea abies (L.) Karst. and Quercus petraea (Matt.) Liebl. were the most frequent, representing $65.9 \%$ of all trees surveyed. With the UFMO method, Qu-
Table 3. Ten most frequent tree species recorded by the ISM and UFMO methods ( $\%$ of all trees inventoried)

Tablica 3. Deset najčešćih vrsta drveća zabilježenih metodama ISM i UFMO (\% svih popisanih stabala)

\begin{tabular}{lcll} 
ISM & \multicolumn{3}{l}{ UFM0 } \\
Pinus sylvestris L. & 23.4 & $\begin{array}{l}\text { Quercus petraea (Matt.) } \\
\text { Liebl. }\end{array}$ & 34.3 \\
Picea abies (L.) Karsten & 23.2 & Castanea sativa Mill. & 21.3 \\
$\begin{array}{l}\text { Quercus petraea (Matt.) } \\
\text { Liebl. }\end{array}$ & 19.3 & Picea abies (L.) Karsten & 19.1 \\
Castanea sativa Mill. & 16.2 & Pinus sylvestris L. & 8.6 \\
Fagus sylvatica L. & 6.9 & Tilia platyphyllos Scop. & 2.9 \\
Quercus robur L. & 4.1 & Carpinus betulus L. & 2.7 \\
Acer pseudoplatanus L. & 2.1 & Acer pseudoplatanus L. & 2.7 \\
Tilia platyphyllos Scop. & 1.4 & Fraxinus excelsior L. & 2.6 \\
Alnus glutinosa (L.) Gaertn. & 1.4 & Alnus glutinosa (L.) Gaertn. & 1.5 \\
Tilia cordata Mill. & 1.0 & Prunus avium L. & 0.8
\end{tabular}

ercus petraea, Castanea sativa Mill., and Picea abies were the most frequent, representing $74.6 \%$ of all trees surveyed. The tree species surveyed by the UFMO method that were not detected by the ISM method represented only $4.5 \%$ of all trees: Abies alba Mill., Acer platanoides L., Aesculus hippocastanum L., Fraxinus excelsior L., Juglans regia L., Larix decidua Mill., Larix leptolepis (Siebold \& Zucc.) Gordon, Prunus domestica L., Robinia pseudacacia L., and Salix spp. The ISM method recorded one tree species that the UFMO method did not detect: Tilia cordata Mill.

The results of the monitoring also comprised specific management recommendations suggested for the trees per

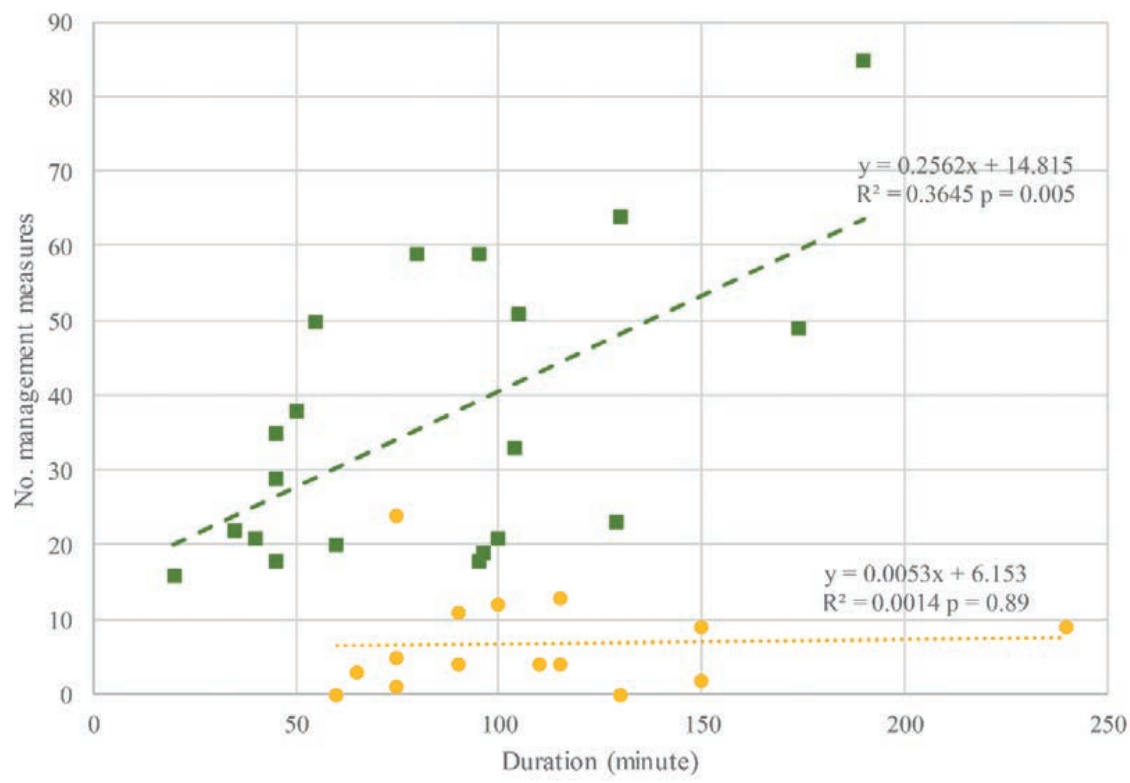

- ISM - UFMO …..... Linear (ISM) - - - Linear (UFMO)

Figure 3. Comparison between ISM and the UFMO method in the number of management measures suggested Slika 3. Usporedba između ISM i UFMO metode u broju predloženih mjera upravljanja 
Table 4. Summary of management measures suggested by the ISM and UFMO methods Tablica 4. Sažetak mjera upravljanja predloženih metodama ISM i UFMO

$\begin{array}{lcccccc}\text { Management measure } & \text { ISM }(\%)^{*} & \text { UFMO (\%) } & \text { ISM (n/ha) } & \text { UFMO (n/ha) } & \text { ISM (n/hour) } & \text { UFMO (n/hour) } \\ \text { Pruning } & 0 & 25.6 & 0.0 & 36.1 & 0.0 & 6.6 \\ \text { Salvage cutting } & 13.9 & 42.1 & 15.2 & 59.3 & 0.5 & 10.8 \\ \text { Sanitation cutting } & 68.3 & 21.5 & 75.0 & 30.3 & 2.5 & 5.5 \\ \text { Tending } & 17.8 & 10.8 & 19.6 & 15.2 & 0.7 & 2.8 \\ \text { Total } & 100 & 100 & 109.8 & 140.9 & 3.7 & 25.8\end{array}$

*Percent of all management measures suggested by the method

method (Table 4). The most frequently suggested management measure by ISM method was sanitation cutting (68.3\%), whereas for the UFMO method, the most frequent was salvage cutting (42.1\%). Pruning was the second most frequently suggested measure (25.6\%) for the UFMO method, whereas for the ISM method it wasn't suggested at all. Tending was suggested by both the ISM and UFMO methods ( $17.8 \%$ and $10.8 \%$, respectively). Altogether, the UFMO method performed better at providing management measures expressed in relative area and relative time, as shown in Table 1.

\section{DISCUSSION AND CONCLUSIONS RASPRAVA I ZAKLJUČCI}

This study focused on the comparing of two methods for surveying urban forest health, with each having different designs and purposes. Consequently, the main difficulty was to find appropriate performance measures common to both methods. The UFMO method exceeded ISM for the all chosen performance measures regarding time, except the amount of data gathered. We concluded that the UFMO method was economically more appropriate for surveying urban forest health because the same area was inventoried in 5.4 times less time than required by ISM. Therefore, we can recommend the UFMO method over ISM for surveying urban forest health. When the purpose of surveying urban forest health is the detailed analysis of smaller areas, the ISM method is appropriate because it takes into a consideration more trees and more damaging agents per unit area in comparison to the UFMO method. In cases when the purpose of the surveying is oriented toward the shortterm management of an urban forest, we would again recommend the UFMO method, which is capable of providing more management measures and finding more standing dead trees per hour and per unit area.

Discrepancies between the two methods were expected because of their different purposes and designs. The survey in the UFMO method focused on areas with a higher number of urban forest visitors, i.e. forest paths and parks, and this is very likely the reason that some damage factors were more frequent, e.g. mechanical damage and leaning (Table 2). The ISM method focuses on crown condition, resulting in a higher frequency of damaging agents on leaves and needles, e.g. Dryocosmus kuriphilus, Erysiphe alphitoides and Lophodermium spp. Furthermore, the ISM method recorded more attribute data than the UFMO method, e.g. symptoms, the affected part of the tree, and the percent of defoliation, which resulted in a slower inventory. Because more time was spent on the single plot, more details were noted for smaller areas, and the ISM method recorded more trees and more damaging agents per unit area.

ISM uses a representative sample that can be used to make inferences with respect to the entire population, i.e. all trees within an urban setting. It was designed to provide several estimates of different population parameters, not just the number or proportion of trees with various health issues. Measurements of trees, dead wood, and small trees were made on the ISM plots. Equivalent measurements were not included as part of the UFMO method. The UFMO method was designed to specifically assess urban tree health; therefore, it is no surprise that it can do this task more efficiently than the ISM method. However, it does not use a representative sample and should not be used to make inferences regarding the entire population. If the UFMO method was applied repeatedly through time in the same areas, it would give an idea of the change in the health status of urban trees through time and perhaps could be used to assess the effectiveness of management activities aimed at improving urban forest health. However, even with this application, the UFMO method would require the assumption that the changes in tree health in the areas being monitored (i.e. the areas immediately along trails) are representative of changes elsewhere within the urban forest if the results are to be generalized over the entire urban area. For the same sampling cost, the ISM approach would produce an unbiased but imprecise estimate of overall forest health, while the UFMO method would produce a biased but more precise estimate. In conclusion, the UFMO method is more appropriate for performing tree health surveys than for monitoring urban forest health.

Primarily, we surveyed paths with a relatively high number of visitors and forest areas that are close to, or even adjacent to, real estate, buildings, roads, etc. Secondarily, we inventoried paths with a relatively low number of visitors. 
Assigning priority to tracks depends on the goal of the survey. The UFMO method was designed for use in urban forests where recreational, aesthetic, and health functions are most important. Therefore, it is reasonable to protect visitors from damaged trees that may fall or may harm the visitor or her/his property. Accordingly, the higher priority tracks have paths with a higher number of visitors and are close to real estate. In our study, we chose paths that were closer to the inventoried ISM plots, which made the ISM and the UFMO methods spatially comparable. Furthermore, ISM is designed to repeat the inventory on the same plots and to calculate trends from past measurements. If we want to calculate trends with the UFMO method, we must monitor the same tracks in an agreed time span, and the tracks must be chosen randomly, otherwise the results are biased and not representative of the whole population. Where the whole population in the UFMO method does not actually mean the urban forest, but only the trees alongside the surveyed paths.

Furthermore, roads and trails are not generally established randomly within an area but are generally found in areas with suitable terrain. There may well be a correlation between terrain and site factors that can influence tree response to insects and pathogens. More importantly, roads and trails receive much higher levels of public use than elsewhere within an urban forest, and consequently trees in the vicinity of roads and trails are more likely to be damaged or stressed as a result of the more frequent use, which could produce biased results. However, these drawbacks must be weighed against the increase in coverage made available by transects (Hiby and Krishna, 2001) and other advantages that the UFMO method offers. We believe that our results would be replicable in transects off the path, e.g. more management options would also be found on an off-path transect. But still when we perform a health survey along forest trails, the results are more useful for urban forest management organisations which are generally more concerned about human safety than monitoring forest health.

Because the UFMO method avoids patches of difficult terrain (e.g. dense vegetation), the transects can be completed faster and with less man-power, thereby reducing the costs of monitoring (Walters, 2010). Although the UFMO method exceeded the ISM method in almost all chosen performance measures, the UFMO method still has several weaknesses. Typically, walking paths, roads, or game trails are chosen to represent the non-linear transect. This leads to bias in the habitat surveyed. Therefore, it is important to consider the focus of the monitoring before implementing transects as the survey method and to plan transects accordingly.

Both the ISM and UFMO methods record the causal agents of tree damage. However, the UFMO method looks one step ahead and only records the damage that requires management measures. This makes the UFMO method much more practical and directly linked with management planning. The UFMO method could be further improved if only the trees that require management measures were recorded. In addition, causal agents could be left out, i.e. only the GPS location and management measure would be noted. If we want to gain deeper insight into urban forest health, an inventory of all damaging agents is not only desirable but required. Taking photos of damaged trees and damaging agents is desired but not required.

There are other methods available to detect and monitor urban tree damage, e.g. remote sensing using visible spectre (Verlič, 2015; Verlič et al., 2015), remote sensing using a novel hyperspectral camera from a UAV or aircraft (Näsi et al., 2018), remote sensing using airborne laser scanner data (Rahman and Rashed, 2015), or citizen science (Roman et al., 2017). Citizen science was successfully used in the LIFE ARTEMIS project, where the UFMO method was used to survey alien plants in the Tivoli, Rožnik and Šiška Hill Landscape Park in MOL by involving volunteers (Marinšek et al., 2018). The numerus low-cost remote sensing technologies based on individual tree analysis and calibrated remote sensing imagery offer great potential for affordable and timely assessment of the health condition of vulnerable urban forests (Rahman and Rashed, 2015; Näsi et al., 2018). However, such novel methods using upto-date technologies usually do not suggest specific management measures for a specific tree nor do they identify the cause of the damage, which is very often the deciding factor in determining which management measures are needed. Here, the UFMO and the ISM methods are superior to these novel methods.

In conclusion, the comparison results, in general, favoured the UFMO method and non-linear transects over ISM and a systematic grid for monitoring urban forest health. Although the UFMO method demonstrated several advantages over ISM in our study, there is still much room for improvement of the UFMO method. Finally, the decision about which method to use depends primarily on the purpose of the surveying, which dictates the core design of the surveying method, and secondly on the economic performance. Furthermore, the ISM monitoring method can be supplemented with the UFMO surveying method in order to capitalize on the potential synergies of combining both approaches.

\section{ACKNOWLEDGEMENTS} ZAHVALA

The study was performed in the framework of the EMoNFUr Project - Establishing a Monitoring Network to Assess Lowland Forest and Urban Plantations in Lombardy and 
Urban Forests in Slovenia (LIFE10 ENV/IT/000399). We are grateful to the Municipality of Ljubljana, who co-financed the project, and Dr. Andrej Verlič for his technical coordination of the project. We are very thankful to Jan Nagel for providing language help and proof reading. We are grateful to two reviewers for their constructive comments, which greatly improved the manuscript.

\section{REFERENCES}

\section{LITERATURA}

- Arnberger, A., 2006: Recreation use of urban forests: An interarea comparison. Urban Forestry \& Urban Greening, 4: 135144, Jena.

- Eichhorn, J., P. Roskams, N. Potočić, V. Timmermann, M. Ferretti, V. Mues, A. Szepesi, D. Durrant, I. Seletković, H.W. Schroeck, S. Nevalainen, F. Bussotti, P. Garcia, S. Wulff, 2016: Part IV: Visual assessment of crown condition and damaging agents, In: Centre, U.I.F.P.C. (Ed.), Manual on methods and criteria for harmonized sampling, assessment, monitoring and analysis of the effects of air pollution on forests, Thünen Institute of Forest Ecosystems, 49, Eberswalde, Germany. http://icpforests.net/page/icp-forests-manual

- Ferretti, M., 1997: Forest Health Assessment and Monitoring - Issues for Consideration. Environmental Monitoring and Assessment, 48: 45-72, Dordrecht.

- Ferretti, M., A. Chiarucci, 2003: Design concepts adopted in long-term forest monitoring programs in Europe-problems for the future? Science of The Total Environment, 310: 171-178, Amsterdam.

- Ferretti, M., R. Fischer, V. Mues, O. Granke, M. Lorenz, 2010: Basic design principles for the ICP Forests Monitoring Networks. Manual part II, Manual on methods and criteria for harmonized sampling, assessment, monitoring and analysis of the effects of air pollution on forests, UNECE ICP Forests Programme Co-ordinating Centre, 22, Hamburg. http://icp-forests. net/page/icp-forests-manual

- Hiby, L., M.B. Krishna, 2001: Line transect sampling from a curving path. Biometrics, 57: 727-731, Washington.

- Innes, J.L., 1993: Methods to estimate forest health. Silva Fennica, 27: 145-157, Vantaa.

- Keller, J.K.-K., C.C. Konijnendijk, 2012: Short communication: a comparative analysis of municipal urban tree inventories of selected major cities in North America and Europe. Arboriculture \& Urban Forestry, 38: 24-30, Champaign.

- Lorenz, M., 2010: Objectives, strategy and implementation of ICP Forests. Manual part I, Manual on methods and criteria for harmonized sampling, assessment, monitoring and analysis of the effects of air pollution on forests, UNECE, ICP Forests, 21, Hamburg. http://icp-forests.net/page/icp-forests-manual

- Marinšek, A., M. de Groot, N. Ogris, L. Kutnar, A. Verlič, J. Kus Veenvliet, S. Rozman, 2018: Report of the survey of alien plants in urban forest of Landscape park Tivoli, Rožnik and Šišenski hrib by involving volunteers. Project LIFE ARTEMIS, output of the action B4, Gozdarski inštitut Slovenije, Zavod RS za varstvo narave in Zavod Symbiosis, 44 p., Ljubljana

- McPherson, E.G., 1993: Monitoring urban forest health. Environmental Monitoring and Assessment, 26: 165-174, Dordrecht.
- Näsi, R., E. Honkavaara, M. Blomqvist, P. Lyytikäinen-Saarenmaa, T. Hakala, N. Viljanen, T. Kantola, M. Holopainen, 2018: Remote sensing of bark beetle damage in urban forests at individual tree level using a novel hyperspectral camera from UAV and aircraft. Urban Forestry \& Urban Greening, 30: 72-83, Jena.

- Nilsson, K., C.C. Konijnendijk, A.B. Nielsen, 2012: Urban forest function, design and management, In: Meyers, R.A. (Ed.), Encyclopedia of Sustainability Science and Technology, Springer New York, 11344-11361, New York. http://dx.doi. org/10.1007/978-1-4419-0851-3_218

- Ogris, N., T. Hauptman, M. De Groot, D. Jurc, 2015: Urban forest health survey on Roznik in Ljubljana in 2013 by two methods, PANGAEA, doi:10.1594/PANGAEA.846301. http://doi. pangaea.de/10.1594/PANGAEA.846301

- Ogris, N., T. Hauptman, D. Jurc, M. De Groot, 2013: Phytopathological monitoring, In: Calvo, E., B. Selleri, A. Verlič, G. Sanesi (Eds.), EMoNFUr Project Life+ Establishing a monitoring network to assess lowland forest and urban plantations in Lombardy and urban forest in Slovenia (LIFE10 ENV/ IT/000399): Monitoring data analysis and processing (Action 12), Slovenian Forestry Institute, 20-22, Ljubljana. http://www. emonfur.eu/pagina.php?sez=86\&pag=543\&label=Intermediat e+products

- Padoa - Schioppa, E., P. Di giovinazzo, L. Kutnar, M. De Groot, G. Colangelo, G. Sanesi, M. Skudnik, M. Kovač, A. Ragazzi, S. Moricca, B. Ginetti, B. Piškur, N. Ogris, T. Hauptman, D. Jurc, R. Comolli, M. Kobal, P. Simončič, 2012: Definition of working protocol of artificial and natural urban and periurban forest sample plots monitoring (Action 5), In: Calvo, E., B. Selleri, A. Verlič, G. Sanesi (Eds.), EMoNFUr Project Life+ Establishing a monitoring network to assess lowland forest and urban plantations in Lombardy and urban forest in Slovenia (LIFE10 ENV/ IT/000399), Slovenian Forestry Institute, 45, Ljubljana. http:// www.emonfur.eu/pagina.php?sez $=86 \& p a g=578 \&$ label=Delive rable+products

- Rahman, M.T., T. Rashed, 2015: Urban tree damage estimation using airborne laser scanner data and geographic information systems: An example from 2007 Oklahoma ice storm. Urban Forestry \& Urban Greening, 14: 562-572, Jena.

- Roman, L.A., B.C. Scharenbroch, J.P.A. Östberg, L.S. Mueller, J.G. Henning, A.K. Koeser, J.R. Sanders, D.R. Betz, R.C. Jordan, 2017: Data quality in citizen science urban tree inventories. Urban Forestry \& Urban Greening, 22: 124-135, Jena.

- Seidling, W., 2004: Crown condition within integrated evaluations of Level II monitoring data at the German level. European Journal of Forest Research, 123: 63-74, Berlin.

- Verlič, A., 2015: Factors of quality and safety of recreation in the urban forest. Doctoral dissertation, University of Ljubljana, Biotechnical Faculty, 105 p., Ljubljana. http://www.digitalnaknjiznica.bf.uni-lj.si/gozdarstvo/dd_verlic_andrej.pdf

- Verlič, A., A. Arnberger, A. Japelj, P. Simončič, J. Pirnat, 2015: Perceptions of recreational trail impacts on an urban forest walk: A controlled field experiment. Urban Forestry \& Urban Greening, 14: 89-98, Jena.

- Walters, J., 2010. Evaluating the suitability of wildlife monitoring methodology for tropical forest conservation: a comparison of transect surveys and camera trapping, Imperial College London, Master Thesis, 77, Imperial College London, Master Thesis. 


\section{SAŽETAK}

Usporedili smo izvedbu dviju metoda praćenja zdravstvenog stanja urbanih šuma. Prva se temelji na sustavnoj mreži (ISM), a druga na nelinearnim transektima (UFMO). Obje metode testirane su tijekom srpnja i kolovoza 2013. u urbanoj šumi Rožnik u općini Ljubljana (MOL). Procijenili smo stanje krošanja i štetnih čimbenika na 15 ISM ploha, istražujući površinu od 92 a u 1.640 minuta. Metoda UFMO korištena je za ispitivanje površine od 518 a za 1.700 minuta. Performanse ISM-a i UFMO metoda bile su 17,8 min/a odnosno 3,28 min/a. U skladu s mjerenjem performansi vremena/površina, UFMO metoda je provedena 5,4 puta brža od ISM metode. Metoda UFMO zabilježila je 1,5 puta više štetnih čimbenika po satu, 2,7 puta više stabala po satu i 13,4 puta više mrtvih stabala po satu. Također je predloženo 7,0 puta više mjera upravljanja po satu. Međutim, gustoća prikupljenih podataka bila je 7,1 puta veća za ISM metodu. Prema odabranim mjernim pokazateljima, ukupna uspješnost metode UFMO premašila je ISM metodu u svim odabranim mjerama uspješnosti izraženim u relativnom vremenu, osim količine prikupljenih podataka. Zaključujemo da, za isti trošak uzorkovanja, ISM pristup proizvodi nepristranu, ali nepreciznu procjenu ukupnog zdravlja šuma, dok metoda UFMO daje pristranu ali precizniju procjenu. Raspravljamo o mogućim poboljšanjima i daljnjim ograničenjima UFMO metode s naglaskom na razlike između dviju metoda praćenja zdravstvenog stanja šuma. Zaključujemo da se metoda praćenja ISM može dopuniti metodom mjerenja UFMO kako bi se iskoristile potencijalne prednosti kombiniranja oba pristupa.

KLJUČNE RIJEČI: pristranost, ICP Forests, ocjenjivanje učinkovitosti, pregled, sustavna mreža, transekt 